\title{
Aktivitas antibakteri Propionibacterium acnes dan formulasi ekstrak etanol biji pinang (Areca catechu, L) dalam krim anti jerawat
}

Antibacterial activity of propionibacterium acnes and formulation of Areca catechu ethanolic extract in anti-acne cream

\author{
Farid Salahudin ${ }^{\mathrm{a}^{*}}$ dan Heru Agus Cahyanto ${ }^{\mathrm{a}^{* *}}$ \\ aalai Riset dan Standardisasi Industri Pontianak \\ E-mail: *farid.salahudin@yahoo.com; **heru-a@kemenperin.go.id
}

Diterima 30 Juli 2019 Direvisi 04 Mei 2020 Disetujui 06 Mei 2020

\begin{abstract}
ABSTRAK
Telah dilakukan penelitian tentang ekstrak etanol biji pinang dalam aktivitasnya menghambat bakteri Propionibacterium acnes serta sebagai bahan aktif dalam formulasi krim anti jerawat. Ekstrak etanol biji pinang mengandung senyawa tanin dan flavonoid dengan kadar masing-masing 8,53 dan 3,70\%. Hasil uji ekstrak etanol biji pinang dengan konsentrasi sebesar 1,2 dan $3 \%$ memiliki aktivitas daya hambat terhadap $P$. acnes sebesar 6,$33 ; 9,33$ dan 11,00 mm. Namun, sediaan krim ekstrak biji pinang dalam konsentrasi $2 \%$ belum mampu menghambat $P$. acnes. Dosis ekstrak biji pinang dalam sediaan krim yang mampu memberikan hambatan adalah 5, 10 dan 15\% masing-masing sebesar 4, 5 dan $8 \mathrm{~mm}$.
\end{abstract}

Kata kunci : ekstrak; jerawat; krim; pinang

\section{ABSTRACT}

The research on Areca catechu ethanolic extract that inhibit Propionibacterium acnes and used as an active ingredient in anti acne cream formulation has been done. Ethanolic extract of areca contains tannin and flavonoid of 8.53 and $3.70 \%$, respectively. Antibacterial test with concentrations of 1,2 and $3 \%$ have an activity to $P$. acnes of 6.33; 9.33 and $11.00 \mathrm{~mm}$. However, cream formulation with $2 \%$ concentration has not inhibit $P$. acnes yet. The dose in the cream formulation that is able to inhibit is 5, 10 and $15 \%$ respectively of 4,5 and $8 \mathrm{~mm}$.

Keywords : extract; acne; cream; areca

\section{PENDAHULUAN}

Pengembangan bahan baku obat terutama dari tanaman, memilki potensi yang besar dalam mendukung kemandirian bahan baku obat di Indonesia, (Kementerian Kesehatan RI, 2015). Sekitar 31 jenis tanaman obat telah dilakukan penelitian dan diketahui memiliki aktivitas sebagai obat, sehingga perlu penelitian dan pengembangan lanjutan agar lebih terarah dalam rangka kemandirian obat (Pribadi, 2015).

Tanaman dari jenis palma salah satunya adalah pinang, dapat dikembangkan untuk menjadi obat pada beberapa penyakit. Di dalam biji pinang terkandung senyawa yang memiliki aktivitas sebagai obat. Biji pinang mengandung beberapa senyawa, seperti alkaloid dengan arecoline $\left(\mathrm{C}_{8} \mathrm{H}_{13} \mathrm{NO}_{2}\right)$ sebagai alkaloid terbanyak (Faden, 2018), senyawa tanin (M. Senthil Amudhan, 2012), lignin dan senyawa fenolik (Wang \& Lee, 1996). Metabolit sekunder biji pinang ini memiliki aktivitas terhadap perkembangan bakteri baik bakteri gram positif atau negatif (Jain et al., 2017), menghambat bakteri Staphylococcus aureus dan Escherichia coli (Faden, 2018), juga terhadap bakteri Propionibacterium acnes (Cahyaningrum, 2014). 
Jerawat merupakan suatu kondisi penyakit radang kronis pada kulit berupa lesi utama yang disebut komedo juga terdapat papula, pustula, nodula (James et al., 2011). Jerawat umumnya timbul pada usia remaja/pubertas, namun ada terjadi pada usia dewasa. Pada jerawat, komedo, yang menyumbat saluran kelenjar minyak atau folikel polisebasea yang mengakibatkan gangguan peradangan yang diakibatkan aktivitas bakteri dalam jerawat (Nakatsuji et al., 2009).

Bakteri penyebab jerawat yang umum adalah bakteri Propionibacterium acnes, merupakan bakteri gram positif, biasa hidup di kulit terutama pada bagian kelenjar minyak. (Desbois \& Lawlor, 2013) Untuk mengatasinya, biasanya digunakan obat golongan antibiotik, seperti eritromisin, klindamisin dan tetrasiklin, namun dapat menimbulkan efek samping yang tidak diinginkan seperti iritasi kulit dan pemakaian antibiotik yang kurang tepat juga menimbulkan masalah resistensi (Eady et al., 2003). Pada penelitian sebelumnya telah dilaporkan penggunaan ekstrak pinang dalam produk sanitizer (Nasution, 2018). Hal ini mendorong penelitian menggunakan tanaman obat yang memiliki aktivitas antibakteri seperti biji pinang.

Pada penelitian ini ekstrak etanol biji pinang yang memiliki aktivitas antibakteri diformulasikan dalam sediaan krim dan dapat digunakan untuk mengobati jerawat. Penelitian ini dilakukan untuk memastikan dosis ekstrak etanol biji pinang dan produknya berupa krim anti jerawat mampu menghambat bakteri jerawat Propionibacterium acnes serta melakukan uji fisik terhadap produk krim yang dibuat.

\section{BAHAN DAN METODE}

Bahan-bahan penelitian antara lain biji pinang, etanol 96\%, asam stearat, cera alba, trietanolamin, nipagin, nipasol, aquadestilata, bakteri uji Propionibacterium acnes (Laboratorium Mikrobiologi Fakultas Kedokteran, UI, Jakarta). Alat-alat yang digunakan adalah oven (Memmert), Homogenizer (Heidolf DIAX 900), blender (Phillips), mikroskop (Nikon TS 100), timbangan analitik digital (Scout pro), Sentrifuse (Kokusan/H-103n), pH meter (Lab 850), LAF (Streamline), Autoclave (Tomy SX-500, Viskosimeter (Brookfield), inkubator (Memmert).

Ekstraksi dilakukan secara maserasi terhadap 100 gram serbuk biji pinang dengan 1 liter etanol teknis $96 \%$ selama 3 hari pada suhu kamar. Filtrat disaring dan diuapkan dengan rotary evaporator sampai didapatkan ekstrak kental bji pinang. Uji Senyawa metabolit sekunder dilakukan untuk mengetahui kadar kandungan kimia yang terdapat dalam ekstrak etanol biji pinang berupa tanin dan flavonoid. Uji anti bakteri dilakukan dengan menggunakan mikroba uji Propionibacterium acnes dan metode difusi agar. Dibuat konsentrasi ekstrak etanol masing-masing $1 \%, 2 \%$, dan $3 \%$ dan diujikan pada media yang telah diinkubasikan bakteri dan kontrol (-) aquadest dan (+) Clyndamicin. Dibiarkan 24 jam dan dilihat zona hambat yang terbentuk. Ukur diameter zona hambat sebagai aktivitas antibakteri ekstrak etanol biji pinang $(\mathrm{mm})$. Formulasi krim dibuat dengan tipe minyak dalam air $(\mathrm{O} / \mathrm{W})$. Formula menggunakan modifikasi formula dari penelitian Dermawan, Pratiwi, \& Kusharyanti (2015) dengan trietanolamin / TEA dan asam stearat sebagai emulgatornya seperti terlihat pada Tabel 1.

Tabel 1. Formula Krim Ekstrak Etanol Pinang

\begin{tabular}{lccccc}
\hline \multirow{2}{*}{ Bahan } & \multicolumn{5}{c}{ Jumlah Bahan } \\
\cline { 2 - 6 } & $\mathrm{K}-$ & $\mathrm{F} 1$ & $\mathrm{~F} 2$ & $\mathrm{~F} 3$ & $\mathrm{~K}+$ \\
\hline Ekstrak Pinang & - & $1 \%$ & $2 \%$ & $3 \%$ & - \\
\hline Clyndamicin & - & - & - & 15 & $1 \%$ \\
\hline Asam stearat & 15 & 15 & 2 & 2 & 15 \\
\hline Cera Alba & 2 & 2 & 1,5 & 1,5 & 1,5 \\
\hline TEA & 1,5 & 1,5 & 8 & 8 & 8 \\
\hline Gliserin & 8 & 8 & Add 100 & \\
\hline Aquadest & & \multicolumn{5}{c}{} \\
\hline
\end{tabular}


Bahan fase minyak berupa asam stearat, cera alba dilelehkan dalam mortar diatas waterbath (set suhu $96^{\circ} \mathrm{C}$, campuran I). Fase air berupa larutan ekstrak etanol dalam aquadest secukupnya, dipanaskan dengan trietanolamin dan gliserin (suhu $70^{\circ} \mathrm{C}$, campuran II). Tambahkan campuran II kedalam campuran I sedikit demi sedikit serta sisa aquadest, aduk kembali. Pasang alat homogenizer, putar dengan kecepatan $8000 \mathrm{rpm}$ sampai terbentuk krim. Tunggu dingin dan masukkan dalam pot krim.

Uji aktivitas antibakteri krim dilakukan terhadap krim ekstrak etanol biji pinang yang memiliki aktifiktas terhadap Propionibacterium acnes yang dipilih. Krim dengan bahan aktif ekstrak etanol diuji dalam media agar yang telah diinokulasikan bakteri Propionibacterium acnes dan diinkubasikan 24 jam. Kemudian dilihat hambatan yang terbentuk dan disertakan kontrol media tanpa ekstrak biji pinang. Dilakukan pula uji krim meliputi organoleptik, homogenitas, $\mathrm{pH}$, viskositas, ukuran globul, daya sebar dan stabilitas mekanik. Rancangan percobaan dalam penelitian ini adalah ekperimental deskriptif kuantitatif dan dilakukan 3 kali ulangan.

\section{HASIL DAN PEMBAHASAN}

\subsection{Simplisia}

Simplisia merupakan bahan alami tanpa pengolahan selain pengeringan yang dimanfaatkan untuk obat (BPOM, 2019) (Kemenkes, 2012). Simplisia biji pinang diperoleh dari Kota Pontianak dengan rendemen $38,6 \%$, spesifikasi warna cokelat, bau khas pinang, rasa pahit dengan kadar air 6,06\% kadar abu 2,23\% dan kadar abu tak larut asam 0,44\%. Kadar air, abu dan abu tak larut asam merupakan parameter nonspesifik simplisia, yang dapat menentukan kualitas bahan baku. Kadar air menentukan stabilitas simplisia, apabila tinggi akan memudahkan kerusakan, karena mudah ditumbuhi oleh jamur. Sementara kadar abu dan abu tak larut akan menentukan kemurnian atau pun adanya cemaran pada bahan (Kemenkes, 2017).

\subsection{Ekstrak Etanol Biji Pinang}

Ekstrak dibuat dengan menggunakan serbuk simplisia dan diekstraksi dengan etanol teknis $96 \%$ secara maserasi. Maserasi merupakan metode sederhana, murah, mudah dan cocok terhadap bahan yang peka panas. Filtrat dipekatkan dengan rotary evaporator, didapatkan ekstrak kental dengan rendemen sebesar $30 \%$ dari berat simplisia.

Ekstrak kental biji pinang memiliki spesifikasi warna cokelat, bau khas pinang, konsistensi kental, dan rasa pahit dengan kadar air 23,7\% kadar abu $0,79 \%$ dan kadar abu tak larut asam 0,005\%. Ekstrak kental memiliki kadar air 23,7\% masih memenuhi kriteria ekstrak kental, yakni rentang kadar air 5-30\% (Voight, 1994). Metabolit sekunder merupakan parameter spesifik ekstrak yang dapat digunakan untuk standardisasi ekstrak.

\subsection{Kadar Tanin dan Flavonoid}

Kadar tanin dan flavonoid pada ekstrak etanol biji pinang yang hasilnya seperti terlihat pada Tabel 2.

Tabel 2. Uji Kandungan Tanin dan Flavonoid

\begin{tabular}{cc} 
Parameter Uji & Ekstrak etanol \\
\hline Kadar Tanin (\%) & 8,53 \\
Kadar Flavonoid $(\%)$ & 3,70 \\
\hline
\end{tabular}

Tanin dan flavonoid pada dasarnya merupakan senyawa fenolik dengan ciri adanya cincin aromatik dan gugus hidroksil $(-\mathrm{OH})$. Flavonoid biasanya terikat dengan gula sebagai glikosida. Tanin merupakan polifenol yang lebih kompleks. Keduanya memiliki aktivitas seperti antibakteri, anti oksidan (Malangngi et al., 2012). Mekanisme antibakteri flavonoid antara lain akibat hambatan pada sintesis asam nukleat, sitoplasma, permeabilitas membran sel (Xie et al., 2015). Sementara tanin mengganggu proses pembentukan dinding sel, sehingga terjadi lisis (Sapara, 2016). 
Tabel 3. Aktivitas Antibakteri Ekstrak

\begin{tabular}{cc}
\hline Konsentrasi ekstrak (\%) & ØLuas zona hambat $(\mathrm{mm})$ \\
\hline 1 & 6,33 \\
2 & 9,33 \\
3 & 11,00 \\
Kontrol (-) & - \\
Kontrol (+)( clyndamicin 1\%) & 19,87 \\
\hline
\end{tabular}

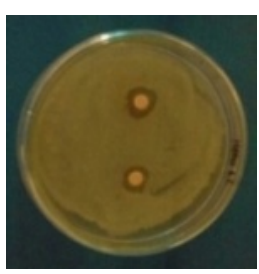

(a)

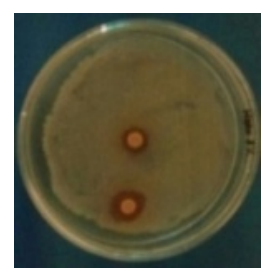

(b)

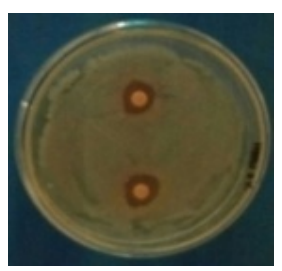

(c)

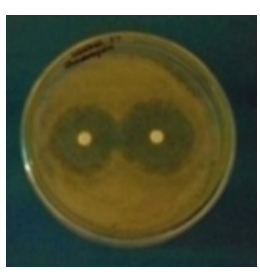

(d)

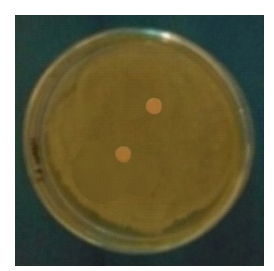

(e)

Gambar 1. Uji Aktivitas Ekstrak Etanol Pinang (a) Konsentrasi 1\%; (b) Konsentrasi 2\% (c) Konsentrasi 3\%; (d) Kontrol Clyndamicin 1\% dan (e) Kontrol (-)

\subsection{Aktivitas Antibakteri}

Uji pendahuluan dilakukan untuk mengetahui dosis aktif ekstrak. Ekstrak etanol dibuat dengan seri konsentrasi ekstrak yaitu $1 \%, 2 \%$ dan $3 \%$ dan kontrol positif antibiotik Clyndamicin dan aquadest sebagai kontrol negatif. Hasil uji aktivitas antibakteri disajikan seperti pada Tabel 3.

Daya hambat ekstrak etanol biji pinang masuk dalam kategori sedang, karena nilainya berkisar antara $5-10 \mathrm{~mm}$ (Rita, 2010). Selanjutnya konsentrasi ekstrak etanol yang digunakan dalam sediaan krim adalah sebesar $2 \%$. Dosis ini dipilih karena memberikan daya hambat terhadap aktivitas antibakteri yang tidak jauh berbeda dengan ekstrak $3 \%$. Hasil uji antibakteri krim ekstrak etanol biji pinang terlihat pada Tabel 4.

Tabel 4. Aktivitas Antibakteri dalam Krim Ekstrak Biji Pinang 2\%

\begin{tabular}{ll}
\hline Ulangan & ØLuas zona hambat $(\mathbf{m m})$ \\
\hline 1 & 0 \\
2 & 0 \\
3 & 0 \\
Kontrol - & 0 \\
\hline
\end{tabular}

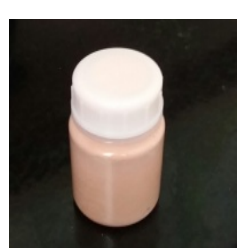

(a)

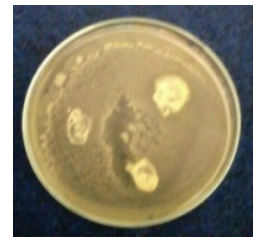

(b)

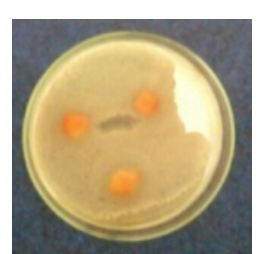

(c)
Gambar 2. Krim Pinang dan Aktivitasnya

(a) Krim Ekstrak Biji Pinang 2\%

(b) Kontrol (-) (c) Aktivitas Krim Ekstrak Biji Pinang 2\%

Krim anti jerawat dengan bahan aktif ekstrak etanol $2 \%$ dibuat menggunakan emulgator TEA. Emulgator TEA akan membentuk krim dengan tipe o/w. Tipe ini dipilih agar dihasilkan krim yang mudah diaplikasikan pada kulit dan tidak lengket di kulit. Namun ekstrak etanol 2\% ternyata tidak memberikan hambatan apabila diaplikasikan dalam sediaan krim. Hal ini dimungkinkan karena bahan-bahan krim mengurangi luas kontak ekstrak yang terkandung sehingga daya hambatnya berkurang. Oleh karena itu dibuat lagi krim dengan bahan aktif ekstrak sebesar 5, 10 dan $15 \%$. Hasil uji ekstrak dalam krim memberikan hambatan seperti disajikan pada Tabel 5. 
Tabel 5. Aktivitas Antibakteri Krim

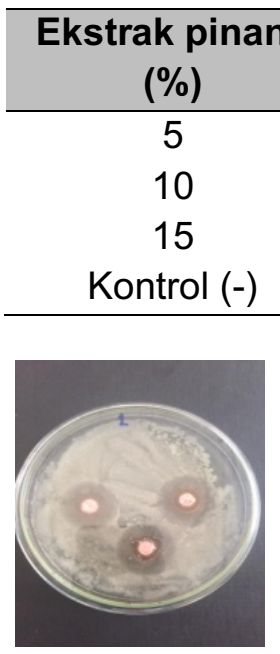

(a)

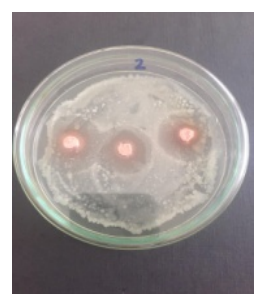

(b)

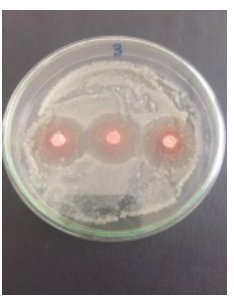

(c)
Gambar 3. Aktivitas Krim Ekstrak Biji

Pinang (a) Konsentrasi 5\%

(b) Konsentrasi 10\% (c) konsentrasi 15\%

Hasil uji formula krim ekstrak etanol biji pinang dengan dosis 5, 10 dan 15\% memberikan aktivitas dalam menghambat bakteri seperti terlihat pada Gambar 3. Adanya kandungan aktif tannin dan flavonoid yang bersifat antibakteri ditunjukkan dengan zona hambatan yang terjadi.

\subsection{Uji Fisik Krim Ekstrak Etanol Biji Pinang}

Hasil uji organoleptik krim ekstak biji pinang meliputi warna cokelat muda, bau khas biji pinang, tidak tengik dan konsistensi semi solid/padat, tidak terdapat partikel kasar. Homogenitas krim pada pengujian menunjukkan krim homogen dan mudah diaplikasikan pada kulit. Ekstrak etanol biji pinang bersifat polar sehingga dilarutkan lebih dahulu ke dalam air, sebelum diemulsikan dalam basis krim dengan suhu $70^{\circ} \mathrm{C}$. Emulgator berupa asam stearat dan trietanolamin membentuk krim tipe M/A (Rowe et al., 2009), yang mudah diaplikasikan pada kulit. $\mathrm{pH}$ krim menentukan keterterimaan krim pada kulit. $\mathrm{pH}$ sediaan yang dapat diterima atau tidak mengiritasi kulit. Rentang $\mathrm{pH}$ krim diusahakan mendekati $\mathrm{pH}$ fisiologis kulit yaitu 4,5-6,5 (Djajadisastra et al., 2007). Hasil pengukuran diperoleh $\mathrm{pH}$ adalah 8,3-
8,4 sedikit diatas derajat keasaman $(\mathrm{pH})$ fisiologis untuk kulit yakni 6,5. Kombinasi asam stearat dan trietanolamin/TEA cenderung menghasilkan krim dengan $\mathrm{pH}$ netral-basa. Asam stearat menjadikan $\mathrm{pH}$ krim rendah, sementara TEA pH krim menjadi tinggi. Kondisi $\mathrm{pH}$ basa menyebabkan kulit menjadi bersisik, kasar. Agar $\mathrm{pH}$ stabil bisa ditambahkan bahan pendapar yang sesuai.

Viskositas krim ditentukan dengan viskosimeter Brokkfield dengan jarum spindle S : 63 dan kecepatan rotasi/putaran $1.0 \mathrm{rpm}$. Nilai viskositas yang diperoleh adalah $7500 \mathrm{cps}$. Viskositas krim sifatnya berlawanan dengan daya sebarnya. Bila viskositas rendah, krim dapat mudah menyebar. Krim yang dihasilkan dengan viskositas $7500 \mathrm{cps}$ krim ekstrak biji pinang mudah menyebar dan mudah diaplikasikan pada kulit. Ukuran droplet emulsi dapat digunakan untuk menentukan stabilitas emulsi krim yang terjadi. Dilihat dengan mikroskop dengan perbesaran 400X ukuran globul diatas $>100 \mu \mathrm{m}$. Selain emulgator, ukuran droplet kecil (skala nano) juga berperan dalam menurunkan tegangan permukaan yang berujung pada stabilitas emulsi (Biradar et al., 2009). Ukuran droplet yang besar (>100 $\mu \mathrm{m})$ tidak stabil karena akan mudah bergabung satu dan lainnya sehingga pecahnya emulsi krim yang terjadi. Daya sebar krim menentukan kemampuan krim menyebar bila diaplikasikan dalam kulit terlihat pada Tabel 6.

Tabel 6. Daya Sebar Krim

\begin{tabular}{cc}
\hline Beban $(\mathrm{gr})$ & Daya sebar $(\mathrm{cm})$ \\
\hline 50 & 6,1 \\
100 & 6,5 \\
150 & 6,7 \\
\hline
\end{tabular}

Daya sebar krim dengan penambahan beban masih dalam rentang persyaratan untuk sediaan topikal yakni 5-7 cm (Banne \& Suatan, 2012). Sentrifus krim ekstrak biji pinang digunakan untuk mengukur stabilitas emulsi krim. Sentrifus dilakukan dengan rpm: 5000 selama 0,5 jam menghasilkan emulsi yang tidak stabil, 
terlihat dari warna yang pecah atau tidak homogen pada krim ekstrak biji pinang.

\section{KESIMPULAN DAN SARAN}

\section{Ekstrak etanol biji pinang} mengandung senyawa metabolit sekunder tanin dan flavonoid dengan kadar 8,53 dan $3,70 \%$. Dosis terbaik dari ekstrak etanol biji pinang yang mampu menghambat pertumbuhan bakteri $P$. acnes yaitu 3\% dengan luas zona hambat sebesar 11,00 $\mathrm{mm}$. Sedangkan dosis terbaik ekstrak etanol biji pinang dalam sediaan krim anti jerawat yang mampu menghambat pertumbuhan bakteri $P$. acnes adalah 15\% dengan luas zona hambat $8 \mathrm{~mm}$.

Untuk pengembangan hasil penelitian ini lebih lanjut perlu dilakukan optimasi formula dan uji stabilitas sediaan krim ekstrak biji pinang serta uji aktivitas ekstrak dengan bakteri penyebab jerawat lain seperti Staphylococcus.

\section{UCAPAN TERIMAKASIH}

Terima kasih kepada Kepala Balai Riset dan Standardisasi Industri Pontianak yang telah memberi dukungan terhadap penelitian ini dan segenap tim penelitian yang terlibat sehingga dapat terselesaikan tepat waktu.

\section{DAFTAR PUSTAKA}

Banne, Y., \& Suatan, R. (2012). Pembuatan salep anti jerawat dari ekstrak rimpang temulawak (Curcuma Xanthorrhiza Roxb.). Jurnal IImiah Farmasi Poltekkes Manado.

Biradar, S. V., Dhumal, R. S., \& Paradkar, A. (2009). Rheological investigation of self-emulsification process: Effect of co-surfactant. Journal of Pharmacy and Pharmaceutical Sciences. https://doi.org/10.18433/j3qc7x

BPOM. (2019). Peraturan badan pengawas obat dan makanan Republik Indonesia. Badan Pengawas Obat Dan Makanan, 32, 1689-1699. https://doi.org/10.1017/CBO97811074 15324.004

Cahyaningrum, G. R. (2014). Aktivitas antibakteri ekstrak etanol biji pinang (Areca catechu Linn) dan fraksinya terhadap pertumbuhan bakteri Propionibacterium acnes, Staphylococcus aureus, Dan Staphylococcus epidermidis. Universitas Muhammadiyah

Purwokerto.

Dermawan, A. M., Pratiwi, L., \& Kusharyanti, I. (2015). Efektifitas krim antijerawat ekstrak metanol daun pacar air (Impatiens balsamina L.). Majalah Obat Tradisional. https://doi.org/10.3390/s120810621

Desbois, A. P., \& Lawlor, K. C. (2013). Antibacterial activity of long-chain polyunsaturated fatty acids against Propionibacterium acnes and Staphylococcus aureus. Marine Drugs, 11(11), 4544-4557. https://doi.org/10.3390/md11114544

Djajadisastra, J., Tranggono, R. I., \& Latifah, F. (2007). Buku pegangan ilmu pengetahuan kosmetik. Jakarta: Gramedia, Hal, 11-13.

Eady, A. E., Cove, J. H., \& Layton, A. M. (2003). Is antibiotic resistance in cutaneous propionibacteria clinically relevant?: Implications of resistance for acne patients and prescribers. In American Journal of Clinical Dermatology. https://doi.org/10.2165/00128071200304120-00002

Faden, A. A. (2018). Evaluation of antibacterial activities of aqueous and methanolic extracts of areca catechu against some opportunistic oral bacteria. Biosciences Biotechnology Research Asia, 15(3), 655-659.

Jain, V., Garg, A., Parascandola, M., Chaturvedi, P., Khariwala, S. S., \& Stepanov, I. (2017). Analysis of alkaloids in areca nut-containing products by liquid chromatographytandem mass spectrometry. Journal of Agricultural and Food Chemistry, 65(9), 1977-1983. https://doi.org/10.1021/acs.jafc.6b051 40

James, W., Elston, D., \& Berger, T. (2011). Andrew's Diseases of the Skin EBook: Clinical Dermatology-Expert 
Consult-Online and Print.

Kemenkes. (2012). Registrasi obat tradisional. Peraturan Menteri Kesehatan Republik Indonesia.

Kemenkes. (2017). Formulasi ramuan obat tradisional Indonesia. 1-14.

Kementerian Kesehatan RI. (2015). Rencana Strategis Kementerian Kesehatan Republik Indonesia Tahun 2015-2019. Pusat Komunikasi Publik. https://doi.org/351.077 Ind $r$

M. Senthil Amudhan, V. H. B. and B. H. (2012). A review on phytochemical and pharmacological potential of areca catechu I. seed ,. 3(11), 41514157.

Malangngi, L., Sangi, M., \& Paendong, J. (2012). Penentuan kandungan tanin dan uji aktivitas antioksidan ekstrak biji buah alpukat (Persea americana Mill.). Jurnal MIPA. https://doi.org/10.35799/jm.1.1.2012.4 23

Nakatsuji, T., Kao, M. C., Fang, J. Y., Zouboulis, C. C., Zhang, L., Gallo, R. L., \& Huang, C. M. (2009). Antimicrobial property of lauric acid against propionibacterium acnes: Its therapeutic potential for inflammatory acne vulgaris. Journal of Investigative Dermatology, 129(10), 2480-2488. https://doi.org/10.1038/jid.2009.93

Pribadi, E. R. (2015). Pasokan dan permintaan tanaman obat indonesia serta arah penelitian dan pengembangannya. Perspektif, 8(1), 52-64.

https://doi.org/10.21082/p.v8n1.2009.

Rita, W. S. (2010). Isolasi, identifikasi, dan uji aktivitas antibakteri senyawa golongan triterpenoid pada rimpang temu putih (Curcuma zedoaria (Berg) Roscoe). Jurnal Kimia.

Rowe, R. C., Sheskey, P., \& Quinn, M. (2009). Handbook of pharmaceutical excipients. Libros DigitalesPharmaceutical Press.

Sapara, T. U. (2016). Efektivitas antibakteri ekstrak daun pacar air (impatiens balsamina I.) terhadap pertumbuhan porphyromonas Pharmacon, 5(4).

Voight, R. (1994). Buku pengantar teknologi farmasi. Yogyakarta, Universitas Gadjah Mada Press.

Wang, C. K., \& Lee, W. H. (1996). Separation, characteristics, and biological activities of phenolics in areca fruit. Journal of Agricultural and Food https://doi.org/10.1021/jf9506110

Xie, Y., Yang, W., Tang, F., Chen, X., \& Ren, L. (2015). Antibacterial activities of flavonoids: structure-activity relationship and mechanism. Current Medicinal Chemistry, 22(1), 132-149. 
Jurnal Riset Industri Hasil Hutan Vol.12, No.1, Juni 2020: 21-28 